\title{
Molecular characterization and biofilm formation potential of Bacillus subtilis and Bacillus velezensis in extended shelf-life milk processing line
}

\section{J. A. Elegbeleye $\bullet$ and E. M. Buys* ${ }^{\circ}$}

Faculty of Natural and Agricultural Sciences, Department of Consumer and Food Sciences, University of Pretoria, Private bag X20, Hatfield 0028, Pretoria, South Africa

\begin{abstract}
This study aims to characterize Bacillus subtilis complex group from raw, pasteurized, and packaged extended shelf-life (ESL) milk samples, to determine their biofilm potential and source-track the microbial contaminants to control their presence during processing. Isolates were characterized using multi-locus sequence typing (MLST) with 7 housekeeping genes. The primers used were designed from the coding regions with the highest number of polymorphic sites. The heat resistance profile indicated that all 12 isolates are psychrotolerant as well as thermophilic, with temperature ranges of $6^{\circ} \mathrm{C}$ to $55^{\circ} \mathrm{C}$ (B43, B44, B52, B54, B55, B56, $\mathrm{B} 57), 6^{\circ} \mathrm{C}$ to $60^{\circ} \mathrm{C}(\mathrm{B} 46, \mathrm{~B} 47, \mathrm{~B} 48)$, and $15^{\circ} \mathrm{C}$ to $60^{\circ} \mathrm{C}$ (B49, B50). A general linear model 2-way repeatedmeasure ANOVA of the biofilm-forming potential of the isolates shows a statistically significant difference across the time of incubation $(6,12,18$, and $24 \mathrm{~h})$. All isolates except 2 formed moderate to strong biofilms, with B44 having the most robust biofilm formation $(3.14 \pm 0.60)$. Scanning electron and confocal microscopy images reveal the strain specificity of the biofilm structure. The MLST analysis identified all isolates as belonging to either B. subtilis or Bacillus velezensis. All the isolates were novel sequence types (ST) when compared with the PubMLST database (https://pubmlst.org/) but showed relatedness to isolates in the raw milk that was processed. The closest ST are 96 for B. velezensis and 128 for B. subtilis, mostly isolated from soil. This study presents the significance of biofilms of thermophilic $B$. subtilis and $B$. velezensis and their possible perpetuation in the dairy processing plant. The information provided is a call for an innovative food contact surface or any other intervention that can minimize or prevent microbial adhesion in the processing plant, to prevent negative effects in ESL milk.
\end{abstract}

Received November 16, 2019.

Accepted February 12, 2020.

*Corresponding author: Elna.Buys@up.ac.za
Key words: biofilm, Bacillus subtilis complex groups, multi-locus sequence typing (MLST), extended shelflife (ESL) milk

\section{INTRODUCTION}

Extended shelf-life (ESL) milk has the inherent characteristic of a shelf-life longer than that of HTST milk, and lacks the burnt flavor commonly associated with UHT milk (Mugadza and Buys, 2018). A temperature regimen that bridges the gap between HTST and UHT processing is employed in the processing of ESL milk (Lorenzen et al., 2011). The challenge of post-process contamination of ESL milk during production was reported in a pilot study (Martin et al., 2018), which found the aseptic filler nozzle highly contaminated with bacteria, with gram-positive bacteria such as Bacillus and Paenibacillus dominating the microflora.

Milk is a nutrient-rich medium widely consumed around the world for its health and sensory benefits. Its neutral $\mathrm{pH}$ and lipid, sugar, and protein contents make it a ready target for microbial spoilage (Srey et al., 2013; Hamadi et al., 2014). Presumably, milk is sterile when derived from a healthy udder, and microbial contamination usually occurs through the contact of raw milk with the udder, teats, and improperly sanitized equipment used in the milking process (Srey et al., 2013). Other sources of milk contaminants include animal feeds, water, and soil (Machado et al., 2017). Processing equipment also acts as reservoirs for bacterial contaminants. The microbial flora of raw milk encompasses genera from both gram-positive and gram-negative bacteria and some fungi. The genera of gram-positive bacteria commonly found in raw milk include Bacillus, Clostridium, Corynebacterium, Microbacterium, Micrococcus, and Staphylococcus, with lactic acid bacteria such as Lactococcus, Lactobacillus, and Streptococcus usually found in high numbers (Quigley et al., 2013; de Oliveira et al., 2015; Vithanage et al., 2016). Of both gram-negative and gram-positive genera, Bacillus and Pseudomonas are dominant in milk because of their ability to sporulate and grow, respec- 
tively, faster than other bacteria under low-temperature conditions (Huck et al., 2008; Meng et al., 2017).

Members of the genus Bacillus are of economic importance in the dairy industry due to the ability of their endospores to survive desiccation, disinfectants, and heat processing, including UHT processing (Huck et al., 2008; Lorenzen et al., 2011). The unaffected spores germinate to form vegetative cells, which, in turn, produce thermostable enzymes and acids causing unfavorable physiochemical changes in the milk (Chen et al., 2003; von Neubeck et al., 2015). The microbial peptidases and lipases hydrolyze the peptide bonds of the milk proteins and glycerol bonds in the milk fat, triggering functional and sensory changes to ESL milk, especially under the condition of long storage (Burgess et al., 2010; Lücking et al., 2013; Baur et al., 2015). Another factor in the economic importance of the genus is its ability to form biofilms on the surface of processing equipment and milking utensils (Sharma and Anand, 2002).

The natural mode of existence of bacteria is a surface-associated community of cells surrounded by extracellular polymeric substances called biofilm, which is the association or aggregation of same or different species of microorganisms (Carpentier and Cerf, 1993; Chmielewski and Frank, 2003). Bacillus spp. have been shown to selectively attach to milk contact surfaces but predominate in the formation of process biofilm due to their ability to form resistant endospores (Seale et al., 2008). Several factors combine to influence the attachment of cells on a food contact surface. These factors comprise the roughness of the surface, presence of conditioning film, electrostatic charge and hydrophobicity of the substratum surface, and composition of the processed product (Araújo et al., 2010; Dat et al., 2014; Peña et al., 2014; Teh et al., 2014; Whitehead and Verran, 2015). Wirtanen et al. (1996) observed that biofilms of some Bacillus spp. adhered more firmly to stainless steel than to Teflon. Thus, the effect flow rate in detaching cells from the substratum during processing is likely not a substantial factor. Bacillus subtilis biofilms produce spores most, especially under lownutrient conditions (Lindsay et al., 2006).

Evidence has established the failure of the $16 \mathrm{~S} \mathrm{rRNA}$ marker to phylogenetically delineate the members of the $B$. subtilis group into their respective taxa because of sequence similarity; hence the suggestion of multilocus sequence typing (MLST) to resolve this challenge in Bacillus systematics (Austin and Bergeron, 1995; Rooney et al., 2009). In dairy processing plants, contamination of product may occur through various sources, such as raw milk, the processing environment, ineffective cleaning-in-place (CIP), and personnel. The growth of biofilms in downstream equipment used in food processing is a major challenge due to their persistence and resistance to cleaning regimens. Previous studies have investigated the adhesive ability of common thermophilic spore formers such as Geobacillus stearothermophilus and Bacillus sporothermodurans of dairy origin, with little data on their molecular characterization and diversity (Jindal et al., 2018). This study therefore focuses on tracking the sources of sporeforming B. subtilis and Bacillus velezensis isolates from different parts of the dairy processing plant, raw milk, and packaged ESL milk using the MLST technique and quantitatively determining their potential to produce biofilms in a simulated dairy environment.

\section{MATERIALS AND METHODS}

\section{Bacterial Selection and Identification}

Twelve isolates of Bacillus spp. from raw milk, pasteurized milk, packaged ESL milk, and ESL milk collected directly from the aseptic filler nozzle, stored at $4^{\circ} \mathrm{C}$, from the Gauteng province of South Africa, were used in the study (Khoza, 2015; Mugadza and Buys, 2017). Samples were collected as follows: $1,000 \mathrm{~mL}$ of raw milk, 1,000 mL of packaged pasteurized milk, 16 packaged ESL milks stored at $4^{\circ} \mathrm{C}(250 \mathrm{~mL}$ each), and 80 swabs taken from different nozzles of aseptic filling machines post-CIP. All samples were collected from the processing line in a total of 4 visits and plated out within $4 \mathrm{~h}$ after collection. Preliminary identification of bacterial isolates was performed via MALDI-TOF MS. Purified bacterial cultures were inoculated on nutrient agar (Oxoid, Basingstoke, UK) and incubated for $24 \mathrm{~h}$. A single colony was picked with a sterile tip and placed in MALDI Biotyper target plates in duplicate (Bruker Daltonics, Bremen, Germany). Typing was done using the protocol of Bittar et al. (2009). The output was analyzed using MALDI Biotyper 3.0 software (Bruker Daltonics). The degree of spectral pattern matching is expressed as a logarithmic identification score and interpreted according to the manufacturer's instructions. Results were expressed as logarithmic values from 0 to 3 levels. Scores $\geq 2.300$ indicate species identification with a high level of confidence; $\geq 2.000$ indicates species identification; 1.700-1.999 indicates genus identification; and $<1.700$ indicates no identification (Croxatto et al., 2012).

\section{Biofilm-Forming Potential}

Adhesion to Polystyrene. A slight adjustment to the protocols described by Hussain and Oh (2017) was used in the quantification of the biomass within the biofilms. Two microliters of an overnight bacterial cul- 
ture grown in Luria broth was added to $200 \mu \mathrm{L}$ of broth of the same medium in 96-well polystyrene microtiter plates. For all experiments, the bacterial inocula were standardized to 1 MacFarland $\left(\sim 3 \times 10^{8} \mathrm{cfu} / \mathrm{mL}\right)$ using a densitometer (Grants Instruments, Cambridgeshire, UK). The plates were incubated at $30^{\circ} \mathrm{C}$ for $6,12,18$, and $24 \mathrm{~h}$. The medium was discarded from each well after incubation. The wells were then carefully washed 3 times by aspiration, using $300 \mu \mathrm{L}$ of PBS (Oxoid), to remove unattached cells. The biomass was stained with $250 \mu \mathrm{L}$ of $0.1 \%$ crystal violet solution (Difco Laboratories Inc., Detroit, MI) for $30 \mathrm{~min}$. Unbound crystal violet was discarded by washing each well 3 times with PBS. To release the bound crystal violet from the biofilm, $200 \mu \mathrm{L}$ of $70 \%$ ethanol was added to each well. The plate was covered with Parafilm (Sigma-Aldrich, St. Louis, MO) and left to stand at room temperature for $30 \mathrm{~min}$. The absorbance of the resulting crystal violet solution was measured at a wavelength of 590 $\mathrm{nm}$ on a microplate reader (Thermo Fisher Scientific, Waltham, MA). The isolates were characterized based on their biofilm-forming potential into non-adherent, weakly, moderately, or strongly adherent, using the method of Stepanović et al. (2000), as follows:

$$
\begin{gathered}
\mathrm{OD}_{\text {cut }}=\mathrm{OD}_{\text {average }} \text { of negative control } \\
+[3 \times \mathrm{SD} \text { of optical density }(\mathrm{OD}) \\
\text { of negative control }] \\
\mathrm{OD} \leq \mathrm{OD}_{\text {cut }}=\text { non-adherent } \\
2 \times \mathrm{OD}_{\text {cut }}<\mathrm{OD} \leq 4 \times \mathrm{OD}_{\text {cut }}=\text { moderately adherent } \\
\mathrm{OD}>4 \times \mathrm{OD}_{\text {cut }}=\text { strongly adherent. }
\end{gathered}
$$

Adhesion on Stainless Steel. The adhesion to stainless steel was tested by modifying the method of Teh et al. (2012). Overnight bacterial culture grown in tryptic soy broth was standardized to 1.0 MacFarland $\left(\sim 3 \times 10^{8} \mathrm{cfu} / \mathrm{mL}\right)$. One milliliter of standardized inoculum was pre-incubated in $2 \mathrm{~mL}$ of reconstituted skim milk for $1 \mathrm{~h}$ for each of the 12 test organisms, and 2 standard strains used as controls. In a centrifuge tube, $4.5 \mathrm{~mL}$ of reconstituted skim milk was inoculated with $0.5 \mathrm{~mL}$ of the pre-incubated cultures to make approximately 1,000 cells in $5 \mathrm{~mL}$. A stainless steel coupon $(316 \mathrm{~L}, 0.90 \mathrm{~mm}, 2 \mathrm{~B}$ PVC; $50 \times 13 \mathrm{~mm})$ was semisubmerged in the tube for each sample and incubated for $24 \mathrm{~h}$. After incubation, the coupons were cleaned by dipping in sterile PBS 3 times to dislodge unattached cells. Samples were prepared for microscopic visualization.

Microbial Adhesion to Hydrocarbon (MATH) Assay. Surface hydrophobicity of the isolates was determined using microbial adhesion to hydrocarbon (MATH) assay, as developed by Rosenberg et al. (1980). Overnight bacterial cultures for all the isolates were washed by centrifuging at 7,000 $\times g$ for $10 \mathrm{~min}$ at $4^{\circ} \mathrm{C}$. The pelleted cells were suspended in sterile distilled water to an optical density at $600 \mathrm{~nm}\left(\mathrm{OD}_{600 \mathrm{~nm}}\right)$. Three milliliters each of hexadecane and the cell suspension were combined and vigorously mixed on a vortex mixer at room temperature for $60 \mathrm{~s}$ and incubated at $30^{\circ} \mathrm{C}$ for $10 \mathrm{~min}$. After $10 \mathrm{~min}$ of incubation, the suspension was agitated on a vortex mixer for $2 \mathrm{~min}$ and allowed to stand for 20 min at ambient temperature (Elhariry, 2011; Chao et al., 2014). The absorbance of the aqueous layer was measured at $\mathrm{OD}_{600 \mathrm{~nm}}$ using a spectrophotometer (Spectronic 200, version 2.06; Thermo Fisher Scientific). The experiment was repeated 3 times in duplicates $(n=6)$. Relative hydrophobicity $(\mathrm{RH})$ is the ratio of the final cell hydrophobicity post-incubation and the initial cell hydrophobicity taken pre-incubation, expressed as a percentage. The percentage cell surface hydrophobicity was calculated using the formula as provided:

$$
\mathrm{RH}=\frac{\text { ODinitial }- \text { ODresidual }}{\text { ODinitial }} \times 100 \%
$$

Heat Resistance Profiles of Isolates. To determine the temperature adaptation of the isolates, the minimum and maximum temperatures for growth were determined by streaking the isolates on nutrient agar (Oxoid) plates and incubated at various temperatures of $15^{\circ} \mathrm{C}$ for psychrophiles, $25^{\circ} \mathrm{C}$ for psychrotrophs, $32^{\circ} \mathrm{C}$ for mesophiles, $55^{\circ} \mathrm{C}$ for thermophiles, and $65^{\circ} \mathrm{C}$ for extreme thermophiles. The plates were incubated between 24 and $48 \mathrm{~h}$, except at $6^{\circ} \mathrm{C}$ with incubation of $10 \mathrm{~d}$. Working bacterial cultures were cryopreserved in $25 \%$ glycerol at $-80^{\circ} \mathrm{C}$ (Duncan et al., 2004; Lorenzen et al., 2011; Ivy et al., 2012).

\section{Electron Microscopy}

Biofilm Structure and Architecture. Approximately 1,000 cells were inoculated into a centrifuge tube containing $4.5 \mathrm{~mL}$ of reconstituted skim milk medium with pre-treated stainless steel coupons in an upright position. The coupons were washed and processed for SEM and confocal laser scanning microscopy (CLSM) after 24-h incubation. The coupons were washed using $0.075 M$ phosphate buffer. The buffer was removed, and 
$2.5 \%$ glutaraldehyde/formaldehyde solution was used to fix the samples for $1 \mathrm{~h}$. The fixative was removed, and samples were washed 3 times in buffer. Later, $1 \%$ osmium tetraoxide solution was added, and samples were post-fixed for $1 \mathrm{~h}$. Samples were washed 3 times for 15 min and centrifuged to obtain a pellet between each step. After removal of the wash buffer, samples were dehydrated using a graded series of ethanol $(30 \%, 50 \%$, $70 \%, 90 \%$, and $3 \times 100 \%$ ) for 15 min each. Samples were left in the last $100 \%$ ethanol for $30 \mathrm{~min}$. Coupons were left in a 50:50 mixture of hexamethyldisilazane (HDMS) and $100 \%$ ethanol for $1 \mathrm{~h}$. The same process was repeated for HDMS only, for another $1 \mathrm{~h}$. Fresh HDMS was later added, and coupons were left to dry. The coupons were coated with carbon before mounting on the SEM (Zeiss, Oberkochen, Germany).

Confocal Laser Scanning Microscopy (CLSM). The stainless-steel coupons were dipped in distilled water 3 times to wash off unattached cells and residual milk. The coupons were later semi-submerged in PBS and stained with $500 \mu M$ propidium iodide (PI) and $1.5 \mathrm{~m} M$ SYTO 9 (Thermo Fisher). The coupons were left for $20 \mathrm{~min}$ in the buffer and observed under the microscope (Zeiss LSM 880).

\section{Multi-Locus Sequencing Analysis (MLST)}

Primer Design for MLST. We performed MLST using 7 housekeeping genes encoding for glycerol uptake facilitator $(g l p F)$, dihydroxy-acid dehydratase $(i l v D)$, phosphotransacetylase (pta), phosphoribosylaminoimidazole carboxy formyl formyltransferase (purH), pyruvate carboxylase $(p y c A)$, RNA polymerase major sigma factor $(r p o D)$, and triose phosphate isomerase (tpiA), according to the pubMLST scheme for Bacillus spp. (https://pubmlst.org/). The universal primers, which were employed in both amplification and sequencing, were designed to amplify a 500- to 600-bp fragment from the coding region of each gene that contained the most polymorphic sites $(\sim 100)$.

DNA Extraction and Sequencing. Extraction of bacterial DNA was performed for all isolates using a bacterial DNA MiniPrep extraction kit (Zymo Research, Irvine, CA). We performed PCR amplification using the same primer set with a final volume of $20 \mu \mathrm{L}$, which consisted of $2 \times 10 \mu \mathrm{L}$ of master mix (EconoTaq PLUS, Lucigen Corp., Middleton, WI): [0.1 unit/ $\mu \mathrm{L}$ of EconoTaq DNA polymerase reaction buffer ( $\mathrm{pH} 9.0$ ), $400 \mu M$ each dNTP, $3 \mathrm{mM} \mathrm{MgCl}_{2}$, and a proprietary mix of PCR enhancer-stabilizer and blue and yellow tracking dyes], $1 \mu \mathrm{L}$ of $\mathrm{gDNA}(30 \mathrm{ng} / \mu \mathrm{L}), 1 \mu \mathrm{L}$ of primer $(10 \mu M)$, and $7 \mu \mathrm{L}$ of nuclease-free water. The thermal cycler program consisted of a pre-heating stage at $94^{\circ} \mathrm{C}$. For initial denaturation of the DNA, the reac- tions were incubated at $94^{\circ} \mathrm{C}$ for $2 \mathrm{~min}$. Denaturation was performed at $94^{\circ} \mathrm{C}$ for $30 \mathrm{~s}$, annealing at $60^{\circ} \mathrm{C}$ for $30 \mathrm{~s}$, and extension at $72^{\circ} \mathrm{C}$ for 1 min for 35 cycles, with the final extension at $72^{\circ} \mathrm{C}$ for $10 \mathrm{~min}$. The PCR products were cleaned using ExoSAP (Thermo Fisher). The ExoSAP master mix was prepared by adding to a $0.6-\mathrm{mL}$ microcentrifuge tube $50.0 \mu \mathrm{L}$ of exonuclease I $(20 \mathrm{U} / \mu \mathrm{L})$ and $200.0 \mu \mathrm{L}$ of shrimp alkaline phosphatase $(1 \mathrm{U} / \mu \mathrm{L})$. We added $10.0 \mu \mathrm{L}$ of PCR mixture to 2.5 $\mu \mathrm{L}$ of the ExoSAP mix. The mixture was vortexed and incubated at $37^{\circ} \mathrm{C}$ for $30 \mathrm{~min}$. The reaction was stopped by heating the mixture to $95^{\circ} \mathrm{C}$ for $5 \mathrm{~min}$. Sequencing was then performed with the ABI v3.1 BigDye Kit (Thermo Fisher). The labeled products were then cleaned with the Zymo Seq Clean-Up Kit, after which the products were injected onto ABI 3500xL Analyzers (Thermo Fisher) with a 50-cm array, using POP-7.

Sequence Alignment and Phylogenetic Analyses. The sequences obtained for all isolates were cleaned, aligned, and prepared for MLST analysis using the Molecular Evolutionary Genetics Analysis software (MEGA-X, version 10.0.05; https://www.megasoftware .net/). Each isolate was characterized based on the combination allelic profile. The allelic sequence was submitted to the PubMLST blast query for B. subtilis (https://pubmlst.org/bsubtilis/) sited at the University of Oxford (UK) to generate the information on the sequence types (ST) and phylogenetic analysis.

\section{Statistical Analysis}

Statistical analysis was performed to determine whether significance difference between bacterial adhesion at $6,12,18$, and $24 \mathrm{~h}$ is more than expected by chance at a $95 \%$ confidence interval. A 2 -way repeatedmeasure ANOVA was conducted to see whether statistically significant difference $(P<0.05)$ occurred in the adhesion to polystyrene among isolates across the periods $(6 \mathrm{~h}, 18 \mathrm{~h}$, and $24 \mathrm{~h}$ ), using the general linear model (GLM). All analyses were performed using GraphPad Prism (version 8.0.2; GraphPad Software Inc., La Jolla, CA).

\section{RESULTS}

\section{Biofilm-Forming Potential}

Comparing isolates visually with the negative control (B. subtilis ATCC 168) revealed differences in their aggregation sites after incubation for $24 \mathrm{~h}$, such as the air-liquid interface and the liquid-solid interface. A noticeable pellicle developed at the top of each well, except for the negative control, as the biofilm matured. We found a substantial main effect for time $F_{1.058,11.64}=$ 
24.73, $P=0.003$, and a significant main effect among the isolates $F_{3.079,33.87}=55.01, P<0.0001$, with all the isolates showing an increase in adhesion capacity across the 4 time periods. This is supported by the results of descriptive statistics with the means across the 4 time periods: $6 \mathrm{~h}($ mean $=0.07174), 12 \mathrm{~h}($ mean $=0.5929)$, $18 \mathrm{~h}($ mean $=0.9787)$, and $24 \mathrm{~h}($ mean $=1.468)$. A significant interaction was also observed between the bacterial isolates and time $F_{5.434,59.78}=13.19, P<$ 0.0001 , with the isolates contributing the largest source of variation $(28 \%)$, followed by time periods $(26 \%)$. The result of the adhesion to polystyrene microtiter plate using tryptose soy broth as a growth medium is summarized in Figure 1.

Isolate B44 showed the greatest biofilm-forming potential at $12 \mathrm{~h}, 18 \mathrm{~h}$, and $24 \mathrm{~h}$ (see Figure 1), with a value of $3.14 \pm 0.60$ after $24 \mathrm{~h}$ of incubation at $32^{\circ} \mathrm{C}$. The biofilm-forming potential of sample B44 was statistically significant $(P<0.05)$ and higher than all other isolates, including the positive control (B. subtilis
ATCC 3610), which showed moderate biofilm-forming ability. Apart from B44, other isolates with strong abilities to form biofilm are B50, B52, and B54, with values of $2.50 \pm 0.69,2.41 \pm 1.20$, and $2.32 \pm 1.41$, respectively. Isolates B56 and B48 showed the lowest biofilm potential, with values of $1.25 \pm 0.77$ and 1.63 \pm 0.58 (Table 1). Isolates 46 and 57 were non-biofilm formers, indicating that adhesion did not necessarily result in biofilm formation. The negative control, B168 (B. subtilis ATCC 168), was observed to have the best adhesive capacity at the incubation period of $18 \mathrm{~h}$, with little or no difference from an incubation time of $24 \mathrm{~h}$.

\section{MATH Assay}

Hydrophobicity of all the isolates was expressed as hydrophobicity percentage, as shown in Figure 2. When the isolates were compared with the positive control reference strain (B. subtilis ATCC 3610), we found a significant difference among the means for all isolates
A

$6 \mathrm{~h}$

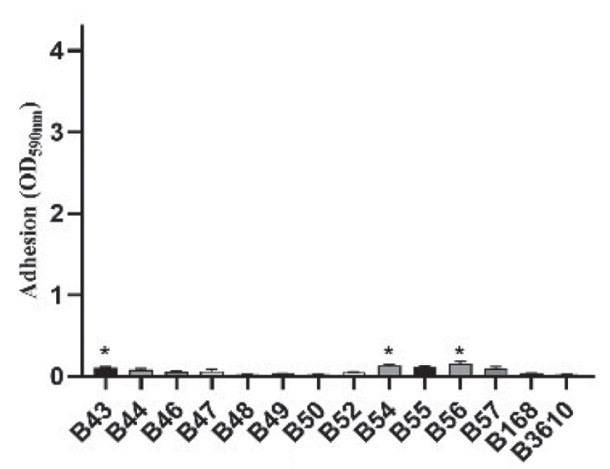

C

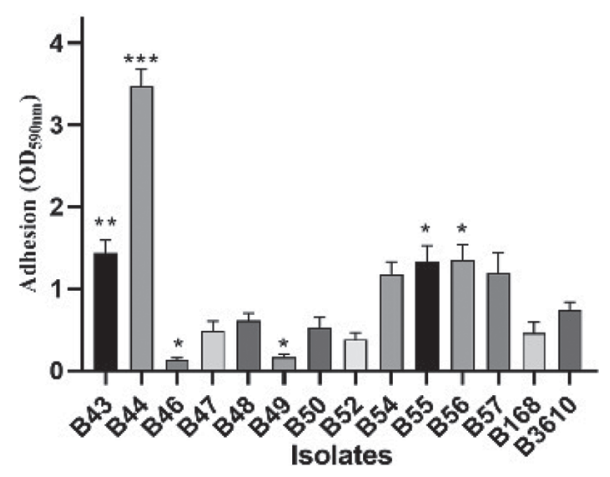

B

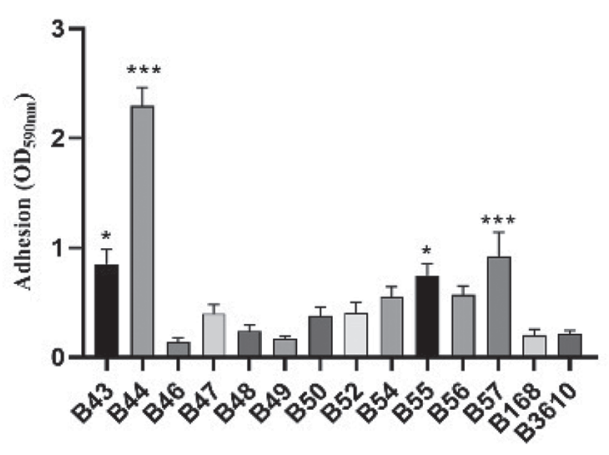

D

$24 \mathrm{~h}$

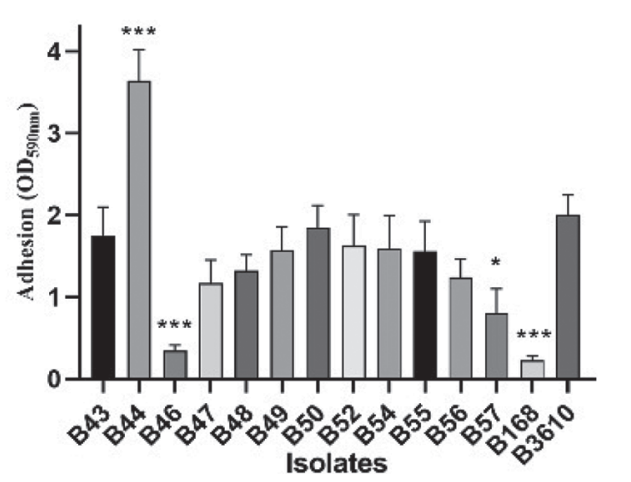

- B. velezensis strain LPL-K103

$\square$ B. velezensis strain LPL-K103

$\square$ B. velezensis strain LPL-K103

$\square$ B. subtilis strain SRCM103689

$\square$ B. subtilis subsp. subtilis str. NCIB 3610

$\square$ B. subtilis strain ATCC 11774

$\square$ B. subtilis strain ATCC 11774

$\square$ B. velezensis strain LPL-K103

$\square$ B. subtilis strain SRCM 103637

B. velezensis strain LPL-K103

$\square$ B. velezensis strain LPL-K103

$\square$ B. velezensis strain LPL-K103

$\square$ B. subtilis ATCC 168

$\square$ B. subtilis ATCC 3610

Figure 1. Total biomass and number of bacterial cells (Bacillus subtilis and Bacillus velezensis) in biofilms formed in 96-well polystyrene microtiter plates with tryptic soy broth at $32^{\circ} \mathrm{C}$ for $6 \mathrm{~h}(\mathrm{~A}), 12 \mathrm{~h}(\mathrm{~B}), 18 \mathrm{~h}(\mathrm{C})$, and $24 \mathrm{~h}(\mathrm{D})$. Total biomass formation was determined using the crystal violet assay at optical density at $590 \mathrm{~nm}\left(\mathrm{OD}_{590}\right)$. Error bars indicate SEM. Differences in biofilm-forming potential among isolates were determined using one-way ANOVA and Tukey's post hoc test $(P<0.05)$. Dunnett's multiple comparison was used to compare isolates with the positive control (B. subtilis ATCC 3610). Asterisks indicate significant differences among means $\left(* P \leq 0.05,{ }^{* *} P \leq 0.01, * * * P \leq 0.001\right)$. Bacillus subtilis ATCC 168 serves as the negative control. 
$(P<0.05)$. Four of the isolates had significantly higher percentage hydrophobicity compared with the positive control strain. These isolates are B44 $(P<0.0001)$, B47 $(P<0.0133)$, B48 $(P<0.0035)$, and B49 $(P<$ $0.0001)$. The highest mean percentage hydrophobicity $(M)$ belonged to B44 $(M=41.2)$, followed by B49 ( $M$ $=40.4)$, with B52 having the lowest $(M=12.8)$. In summary, all isolates demonstrated better hydrophobicity to hexadecane than the reference strain $(M=$ $20.2)$, except B43 $(M=13.5), \mathrm{B} 50(M=15.4), \mathrm{B} 52(M$ $=12.8)$, and the negative control reference strain $B$. subtilis ATCC $168(M=15.3)$.

\section{Heat Resistance Profile}

Isolates demonstrated the ability to grow across all the temperature ranges: psychrophilic $\left(6^{\circ} \mathrm{C}\right)$, psychrotrophic $\left(15^{\circ} \mathrm{C}\right)$, mesophilic $\left(32^{\circ} \mathrm{C}\right)$, and thermophilic $\left(55^{\circ} \mathrm{C}\right)$ temperatures (Table 1$)$. Three of the isolates (B46, B47, and B48), all belonging to the species $B$. subtilis, were able to grow within a temperature range of 6 to $60^{\circ} \mathrm{C}$, with the rest of the isolates growing at $6^{\circ}$ to $55^{\circ} \mathrm{C}$, except B49 and B50.

\section{Microscopy}

As we see in Figure 3, all isolates adhered to the coupons to varying degrees and with varying attachment strength, biovolume, thickness, and biofilm architecture. Spatial stratification can be seen in most of the biofilms, except B168 (negative control) and B46. The structure ranges from multiple-layer biofilm with honeycomb-like channels in most of the isolates, as seen in B49 and B3610, to a flat structure with low biovolume, as observed in B46. Extracellular polymeric substances linking cells at the surface are visible in most of the images. The CLSM shows the distributions between dead and living bacterial cells. The red-stained dead cells are visible in the center of the biofilm structure, with green-stained living cells around the biofilm. Generally, better biofilm formation appears to occur on the stainless steel coupons compared with the polystyrene microtiter plates.

\section{MLST}

The MLST analysis was performed by comparing the sequences from the isolates with the PubMLST database for B. subtilis (https://pubmlst.org/bsubtilis/ ). All isolates were identified as new ST, as shown in Table 2. Closely related ST are identified based on the degree of similarity in the alleles. We found 9 closely related ST, based on the output: ST1, ST3, ST105, ST69, ST96, ST151, ST40, ST161, and ST128, with ST96 as the most abundant $(n=5)$. This result suggests that some of the isolates with related ST have the same source of contamination despite their isolation in different parts of the processing equipment. Most ST were isolated from soil, where they can quickly spread along the food chain, as in the contamination of raw milk and subsequent survival of processing conditions. According to Table 2, other sources of their isolation include corn starch, rhizosphere, naturally fermented feed, and fecal matter of pigs and humans.

Table 1. Adhesive capacity, biofilm potential, cell surface hydrophobicity, and heat resistance profile of Bacillus subtilis and Bacillus velezensis from milk samples [extended shelf life (ESL), raw, pasteurized, and packaged milk samples from raw milk, packaged ESL milk, pasteurized milk tank, and stored ESL milk]; isolate B44 (B. velezensis strain LPL-K103) has the highest percentage hydrophobicity as well as biofilm formation on polystyrene, with the ability to grow at a temperature range of 6 to $55^{\circ} \mathrm{C}^{1}$

\begin{tabular}{|c|c|c|c|c|c|}
\hline Isolate & $\begin{array}{l}\text { Adhesion to } \\
\text { polystyrene } \\
(\text { mean } \pm \mathrm{SD})\end{array}$ & $\begin{array}{l}\text { Biofilm- } \\
\text { forming } \\
\text { potential }\end{array}$ & $\begin{array}{c}\text { Hydrophobicity } \\
(\%)\end{array}$ & $\begin{array}{l}\text { Growth } \\
\text { range } \\
\left({ }^{\circ} \mathrm{C}\right)\end{array}$ & Source of isolate \\
\hline B. velezensis LPL-K103 (B43) & $1.89 \pm 0.78$ & Moderate & $13.5 \pm 2.30$ & $6-55$ & Raw milk \\
\hline B. subtilis SRCM103689 (B47) & $1.74 \pm 0.90^{*}$ & Moderate & $28.8 \pm 1.27$ & $6-60$ & Raw milk \\
\hline B. subtilis ssp. subtilis NCIB 3610 (B48) & $1.63 \pm 0.58^{* *}$ & Moderate & $30.0 \pm 1.19$ & $6-60$ & Raw milk \\
\hline B. velezensis LPL-K103 (B52) & $2.41 \pm 1.20$ & Strong & $12.8 \pm 1.05$ & $6-55$ & Raw milk \\
\hline B. subtilis SRCM103637 (B54) & $2.32 \pm 1.41$ & Strong & $25.6 \pm 1.47$ & $6-55$ & Packaged ESL milk \\
\hline B. velezensis LPL-K103 (B57) & $0.54 \pm 0.45$ & None & $26.0 \pm 3.06$ & $6-55$ & Packaged ESL milk \\
\hline B. velezensis LPL-K103 (B44) & $3.14 \pm 0.60^{* * * *}$ & Strong & $41.2 \pm 1.70$ & $6-55$ & Packaged ESL milk \\
\hline B. velezensis LPL-K103 (B55) & $2.03 \pm 1.40$ & Moderate & $25.3 \pm 0.63$ & $6-55$ & Pasteurized milk tank \\
\hline B. velezensis LPL-K103 (B56) & $1.25 \pm 0.7708$ & Moderate & $26.3 \pm 0.99$ & $6-55$ & Pasteurized milk tank \\
\hline B. subtilis ATCC 168 (negative control) & $0.19 \pm 0.13$ & None & $15.3 \pm 1.77$ & NA & Culture collection \\
\hline B. subtilis ATCC 3610 (positive control) & $2.00 \pm 0.84$ & Moderate & $20.2 \pm 2.84$ & NA & Culture collection \\
\hline
\end{tabular}

${ }^{1} \mathrm{NA}=$ data not available for the reference strains. For temperature profiles, isolates were incubated at $6^{\circ} \mathrm{C}(10 \mathrm{~d}), 10^{\circ} \mathrm{C}(10 \mathrm{~d}), 15^{\circ} \mathrm{C}(4$ to $6 \mathrm{~d})$, $55^{\circ} \mathrm{C}(48 \mathrm{~h})$, and $60^{\circ} \mathrm{C}(48 \mathrm{~h})$. Growth at $6^{\circ} \mathrm{C}$ was observed to be very slow and small.

*Asterisks indicate significant differences among means: ${ }^{*} P \leq 0.05,{ }^{* *} P \leq 0.01$, ${ }^{* * * *} P<0.0001$. 

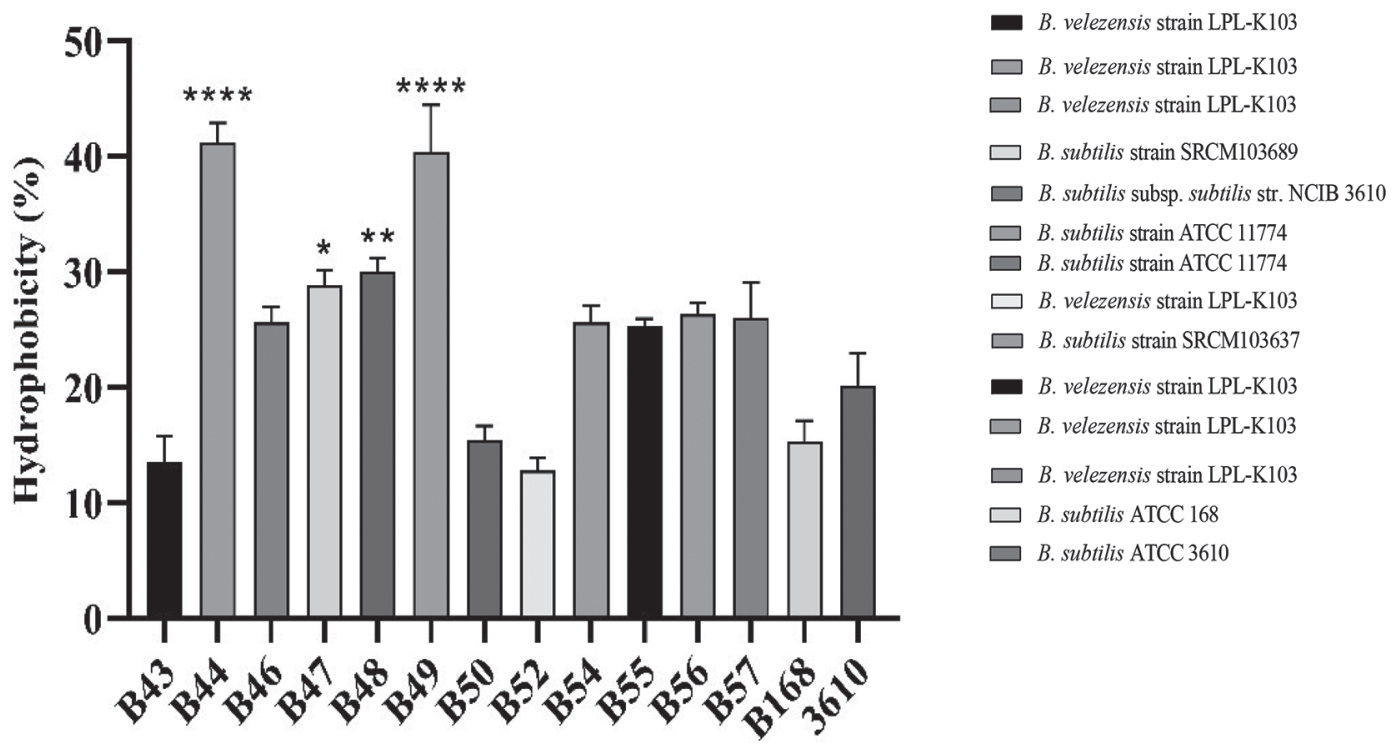

\section{Isolates}

Figure 2. Results of microbial adhesion to hydrocarbon (MATH) assay, showing percentage hydrophobicity of all the isolates (Bacillus subtilis and Bacillus velezensis). Error bars indicate SEM. Adhesive capacity was determined using one-way ANOVA and Dunnett's multiple comparison for the post hoc test $(P<0.05)$, comparing all the isolates with the positive control (B. subtilis ATCC 3610). Asterisks indicate significant differences among means $\left(* P \leq 0.05,{ }^{* *} P \leq 0.01,{ }^{* * * *} P<0.0001\right)$.

\section{DISCUSSION}

Bacillus velezensis has not previously been associated with the challenges of biofilm formation and contamination in dairy processing equipment and products. However, a previous study by Duanis-Assaf et al. (2016) reported quorum sensing and biofilm formation in B. subtilis to be dose-dependent to the presence of sugar lactose in milk. We observed the ability of all the isolates to form moderate to strong biofilms on polystyrene microtiter plates, except for B46 and B57. In contrast, all isolates seemed to have better biofilmforming ability on stainless steel, based on observation of SEM and CLSM images. This variation in adhesion to different substrata (polystyrene vs. stainless steel) can be attributed to the physicochemical characteristics of the surfaces, such as surface charge, hydrophobicity, nanotopography, and presence of conditioning film (Legeay et al., 2010). Apart from the stereo-specific interactions of bacterial cells in the adhesive strength of isolates, surface characteristics also play an essential role. The present result indicated that bioadhesive and biofilm-forming potential is strain-specific for members of the B. subtilis complex group used in the study. Environmental stresses have been suggested to be responsible for the quantitative variations in the potentials of strains to form biofilm (Elhariry, 2011). This result regarding differences in biofilm formation among strains is consistent with other similar studies, such as observed variations in strains of Candida albicans ( $\mathrm{Li}$ et al., 2003; Barak et al., 2007).

The results of the MATH assay revealed that isolate B44 possesses strong biofilm-forming and adhesion capacity through hydrophobic interaction with substrata such as stainless steel, which is commonly used in the food industry. Despite the ability of B43 to form a moderate biofilm, it has very low adhesion to the hydrocarbon used in the MATH assay (hexadecane). We can safely conclude that despite hydrophobic interaction of bacterial cells with a substratum playing a critical role in the initiation of the biofilm-forming process, other intrinsic and extrinsic factors such as the growth rate of the contaminating bacteria, $\mathrm{pH}$, temperature, nutrient composition of the medium, quorum sensing, presence of other bacteria, and more, are equally important in the overall biomass and structure of the biofilm (Tirumalai, 2015; Bohinc et al., 2016). As in the results of the biofilm assay, we observed that bacterial cell surface hydrophobicity is strain-specific, with all the isolates having percentage hydrophobicity of less than $50 \%$ (or 0.5); hence, they can safely be classified as hydrophilic rather than hydrophobic based on their cell surface properties.

The SEM and CLSM images of isolates revealed that all isolates produced microcolonies on a stainless steel surface using reconstituted milk medium, producing 
biofilm with different adhesive abilities, except for isolates B48 and B168, which were not well-defined. The structure or biofilm architecture seems to be straindependent, as in the case of adhesion ability on a polystyrene surface. Spatial stratification and extracellular polymeric substances can be conspicuously seen in all the isolates but to varying degrees, producing a meshlike connection between one cell and another as well as to the substratum. This type of multi-layered stratification in a biofilm is capable of driving phenotypic heterogeneity and morphological differentiation of cells within a biofilm matrix and the formation of spores within the processing plant, which can perpetuate the problem of contamination and spoilage of product being processed within the processing equipment (Soni et al., 2016). Diverse phenotypes or cell types have been identified within the B. subtilis biofilm, specialized for production of metabolites such as surfactin, matrix, and exoproteases, as well as spores and motile cells (Veening et al., 2008; Lopez et al., 2009; Marlow et al., 2014). In the confocal images, the nonviable or older cells stained orange or red, whereas green cells are metabolically active, viable cells. We can infer that the biofilm expands from within the center of the struc- ture outward, with actively dividing cells surrounding the structure. Because the isolates are spore-forming bacilli, it can be concluded that center of the biofilm structure is the hotbed of spore production and a probable source of bacterial recontamination in the plant and resistance to CIP regimens. Production of spores is not limited only to this site within the cluster of bacterial cells but can also be distributed throughout the biofilm as well as in patches, as observed by Faille et al. (2014). The heat resistance profile showed that all isolates were able to grow at temperatures ranging from psychrotolerant to thermophilic on nutrient agar. Specifically, all the isolates can be divided into 3 categories according to their heat resistance profiles: $6^{\circ} \mathrm{C}$ to $55^{\circ} \mathrm{C}(\mathrm{B} 43, \mathrm{~B} 44, \mathrm{~B} 52, \mathrm{~B} 54, \mathrm{~B} 55, \mathrm{~B} 56, \mathrm{~B} 57), 6^{\circ} \mathrm{C}$ to $60^{\circ} \mathrm{C}(\mathrm{B} 46, \mathrm{~B} 47, \mathrm{~B} 48)$, and $15^{\circ} \mathrm{C}$ to $60^{\circ} \mathrm{C}(\mathrm{B} 49, \mathrm{~B} 50)$. The implication is that all the isolates are capable of surviving pasteurization conditions as well as surviving storage and refrigeration temperatures as vegetative cells. This means that the eradication of these isolates may prove to be a challenge, as they can form process biofilms, spores, and vegetative cells that can survive the high temperatures employed during the pasteurization process.
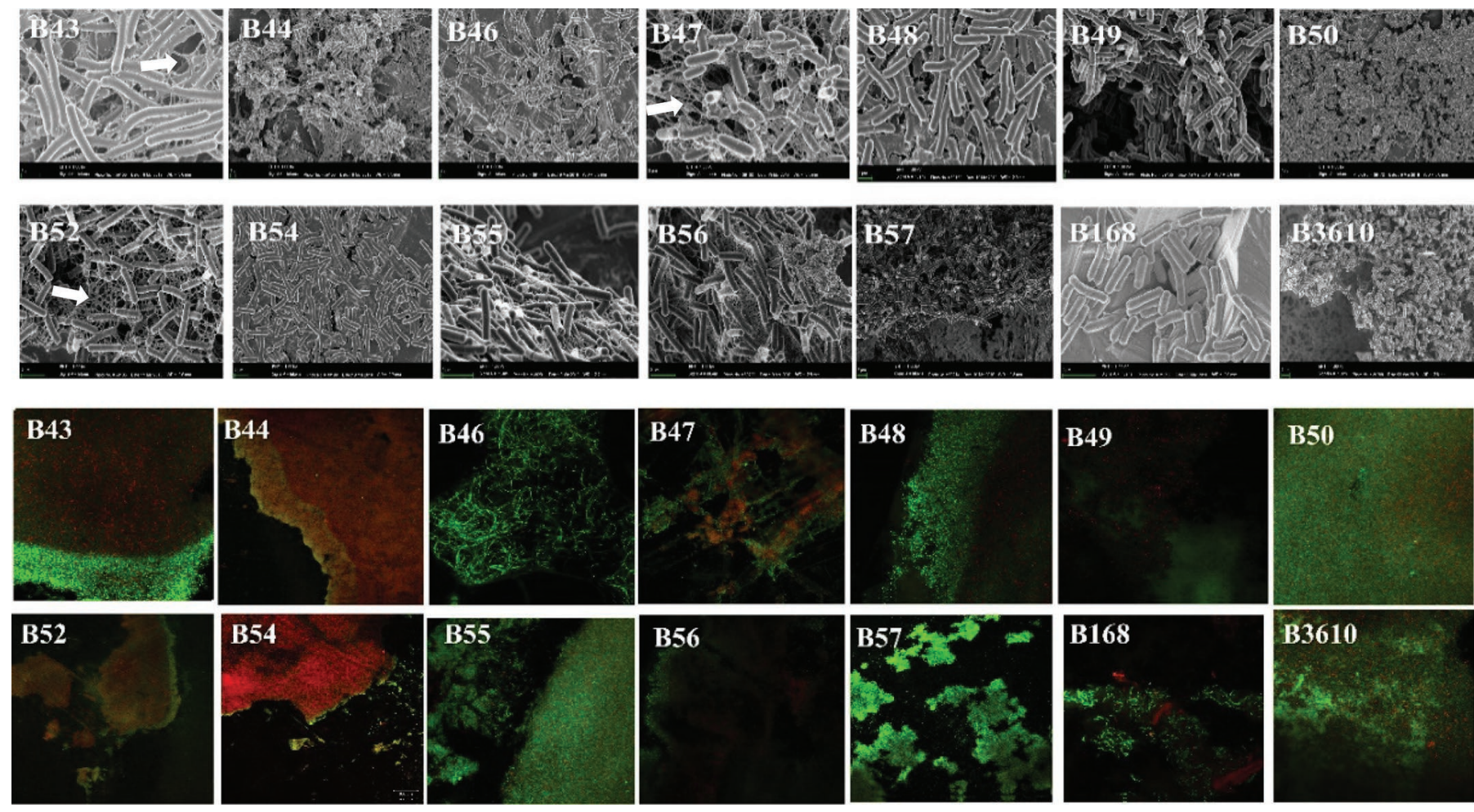
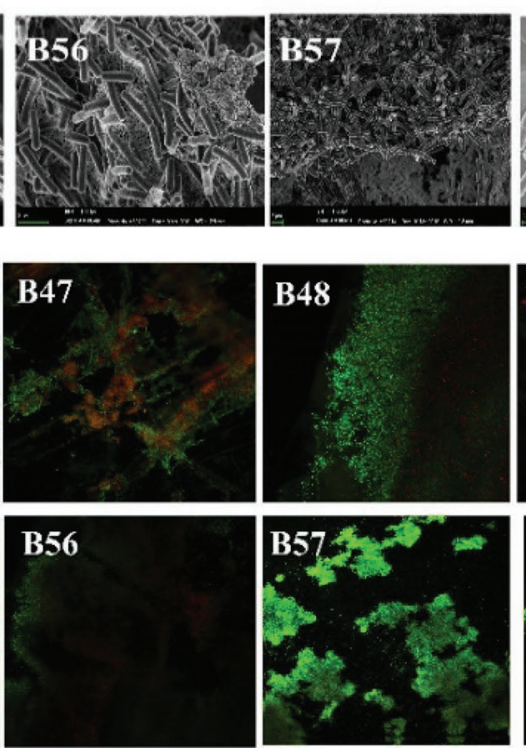
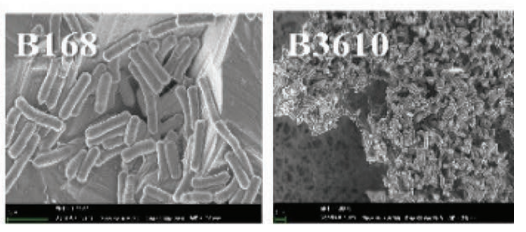

Figure 3. Scanning electron micrographs and confocal laser scanning microscopy images of adhesion of Bacillus subtilis and Bacillus velezensis isolates on stainless steel coupons semisubmerged in reconstituted skim milk at $32^{\circ} \mathrm{C}$. Arrows indicate the presence of mesh-like extracellular polymeric substances between cells within the biofilm matrix. Spatial stratification in the architecture can be clearly seen in some of the isolates, such as B44, B49, B55, and the positive control B3610. 
Elegbeleye and Buys: BACILLUS SUBTILIS CHARACTERIZATION AND BIOFILM FORMATION

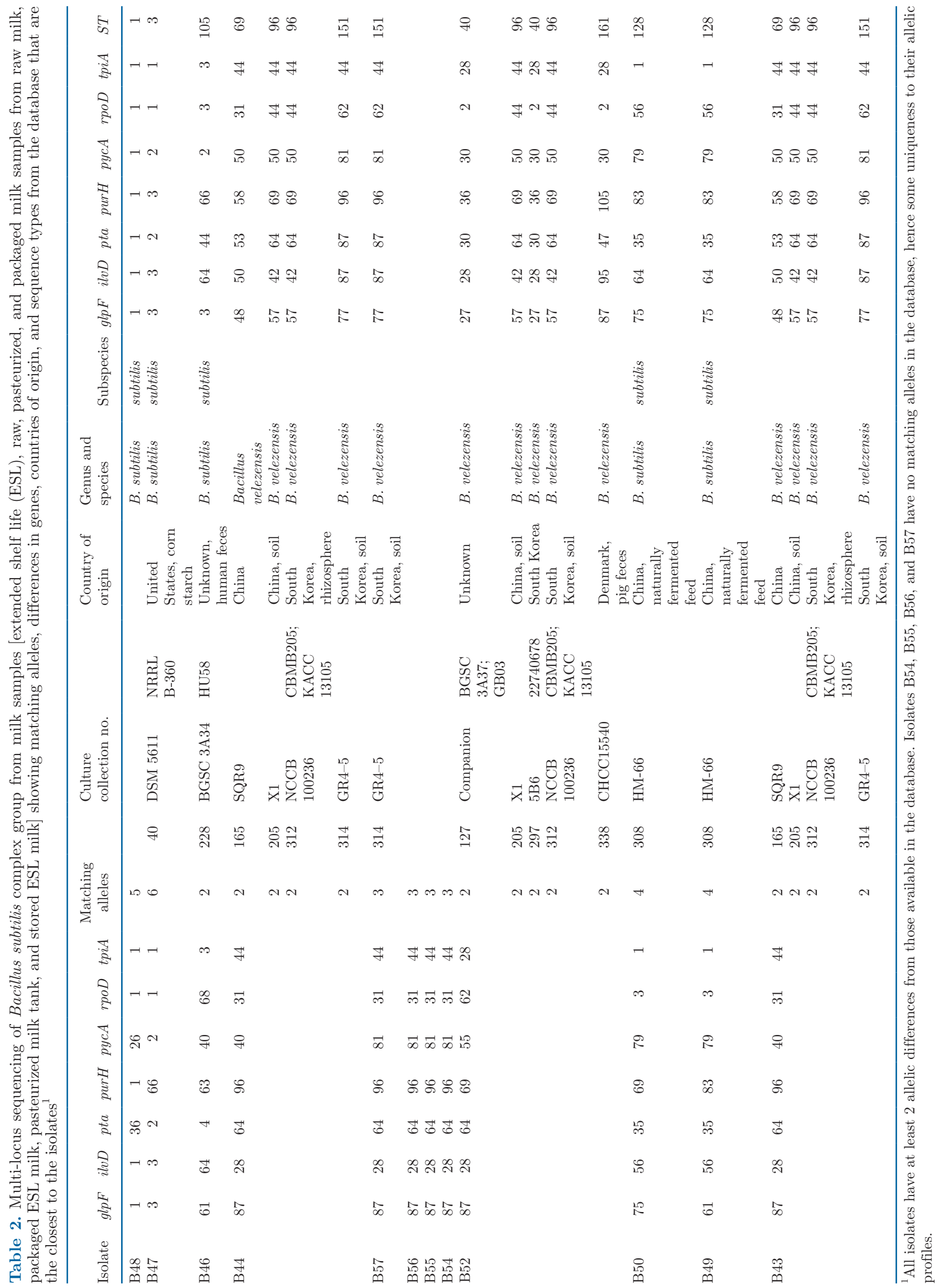


The MLST analysis identified the strains of species of Bacillus contaminants in B. subtilis and B. velezensis. Six isolates were identified as strain $B$. velezensis LPLK103 after a BLAST analysis of the concatenation of all 7 housekeeping genes used. The strain was isolated from raw milk, the pasteurized milk tank, and packaged ESL milk, suggesting a possible adaptation of the strain to pasteurization conditions. Such adaptive features include spore and biofilm production, cell-surface hydrophobicity, heat resistance of spores and vegetative cells, and good attachment strength to stainless steel surfaces. This study verifies that the isolates possess at least some of these properties. Other strains of B. subtilis identified are B. subtilis ATCC 11774 (ESL milk at $5^{\circ} \mathrm{C}$ and $7^{\circ} \mathrm{C}$ ), B. subtilis ssp. subtilis NCIB 3610 (raw milk), B. subtilis SRCM101392 (raw milk), B. subtilis SRCM103689 (raw milk), and B. subtilis SRCM103637 (packaged ESL milk). The result of a similar study with a focus on Bacillus cereus using the same milk samples implicates the aseptic filler-nozzle as a possible reservoir for these thermophilic spore formers during ESL milk processing (Mugadza et al., 2019).

A limitation of the study is that the biofilm-forming potential of the strains was tested under static conditions, unlike the flow conditions during processing of ESL milk. Although it is possible that the ESL processing conditions preselected the isolates due to their ability to produce spores and tolerate thermophilic temperatures (above $50^{\circ} \mathrm{C}$ ), biofilms naturally exist in a multispecies consortium rather than the monospecies biofilms assumed in this study. Nonetheless, the study proves that isolates of $B$. velezensis, hitherto unknown as a challenge during milk processing, as well as other well-known Bacillus species, may be important in ESL milk processing.

This study used MLST to track the sources of contamination of B. subtilis and B. velezensis in an ESL processing plant. From all indications, the isolates are linked to the raw milk used in the production of ESL milk, because they are clonally related. They seem to be well adapted to survive the selective pressure created during processing, as either vegetative cells or spores. Although B. subtilis and B. velezensis are generally nonpathogenic, this study demonstrates their biofilm-forming ability and the potential to constitute a nuisance in a processing plant, where they compromise the quality of the ESL milk during extended storage after processing. This challenge may be aggravated in a scenario in which CIP is ineffective against spores of the organisms and the plant is shut down before the commencement of another processing round. This study is a part of a cohort with the specific aim of characterizing spore-forming bacilli in ESL milk and their intrinsic resistance to CIP and other control measures.
The goal is to mitigate or totally eradicate the challenge of thermophilic spore formers and their potential effects on both the dairy industry and consumers.

\section{CONCLUSIONS}

The quality of raw milk used in the production of ESL milk is crucial. Based on our results, the source of contamination seems to be the raw milk used. From this standpoint, it imperative to implement actions designed to minimize risk of bacterial contaminants at the farm level. However, the hygiene conditions of the dairy processing environment, the bulk milk tank, the tanker used during transport of raw milk, the processing equipment, and personnel must be prioritized to avoid the persistence challenge of biofilms of thermophilic spore formers.

\section{ACKNOWLEDGMENTS}

The authors acknowledge the support of the National Research Fund (Pretoria, South Africa) in the provision of the MALDI-TOF biotyper at the Department of Microbiology and Plant Pathology, Faculty of Natural and Agricultural Sciences, Pretoria. We also acknowledge Zama Zulu (Department of Plant and Soil Sciences, University of Pretoria) for technical assistance in MALDI-TOF biotyping and Dan Zeigler, director of the Bacillus Genetic Stock Centre of the Ohio State University (Columbus, Ohio), for information on the universal primers used in this study. The authors declare that they have no conflict of interest.

\section{REFERENCES}

Araújo, E. A., N. J. de Andrade, A. F. de Carvalho, A. M. Ramos, C. A. de Sá Silva, and L. H. M. da Silva. 2010. Colloidal aspects of microorganism adhesion. Nat. Chem. 33:1940-1948. https://doi .org/10.1590/S0100-40422010000900022.

Austin, J. W., and G. Bergeron. 1995. Development of bacterial biofilms in dairy processing lines. J. Dairy Res. 62:509-519. https:// doi.org/10.1017/S0022029900031204.

Barak, J. D., C. E. Jahn, D. L. Gibson, and A. O. Charkowski. 2007. The role of cellulose and $\mathrm{O}$-antigen capsule in the colonization of plants by Salmonella enterica. Mol. Plant Microbe Interact. 20:1083-1091. https://doi.org/10.1094/MPMI-20-9-1083.

Baur, C., M. Krewinkel, B. Kranz, M. von Neubeck, M. Wenning, S. Scherer, M. Stoeckel, J. Hinrichs, T. Stressler, and L. Fischer. 2015. Quantification of the proteolytic and lipolytic activity of microorganisms isolated from raw milk. Int. Dairy J. 49:23-29. https: //doi.org/10.1016/j.idairyj.2015.04.005.

Bittar, F., Z. Ouchenane, F. Smati, D. Raoult, and J. M. Rolain. 2009. MALDI-TOF-MS for rapid detection of staphylococcal PantonValentine leukocidin. Int. J. Antimicrob. Agents 34:467-470. https: //doi.org/10.1016/j.ijantimicag.2009.03.017.

Bohinc, K., G. Dražić, A. Abram, M. Jevšnik, B. Jeršek, D. Nipič, M. Kurinčič, and P. Raspor. 2016. Metal surface characteristics dictate bacterial adhesion capacity. Int. J. Adhes. Adhes. 68:39-46. https://doi.org/10.1016/j.ijadhadh.2016.01.008. 
Burgess, S. A., D. Lindsay, and S. H. Flint. 2010. Thermophilic bacilli and their importance in dairy processing. Int. J. Food Microbiol. 144:215-225. https://doi.org/10.1016/j.ijfoodmicro.2010.09.027.

Carpentier, B., and O. Cerf. 1993. Biofilms and their consequences, with particular reference to hygiene in the food industry. J. Appl. Bacteriol. 75:499-511. https://doi.org/10.1111/j.1365-2672.1993 .tb01587.x.

Chao, Y., F. Guo, H. H. P. Fang, and T. Zhang. 2014. Hydrophobicity of diverse bacterial populations in activated sludge and biofilm revealed by microbial adhesion to hydrocarbons assay and highthroughput sequencing. Colloids Surf. B Biointerfaces 114:379385. https://doi.org/10.1016/j.colsurfb.2013.10.028.

Chen, L., R. M. Daniel, and T. Coolbear. 2003. Detection and impact of protease and lipase activities in milk and milk powders. Int. Dairy J. 13:255-275. https://doi.org/10.1016/S0958-6946(02)00171-1.

Chmielewski, R. A. N., and J. F. Frank. 2003. Biofilm formation and control in food processing facilities. Compr. Rev. Food Sci. Food Saf. 2:22-32. https://doi.org/10.1111/j.1541-4337.2003.tb00012.x.

Croxatto, A., G. Prod'hom, and G. Greub. 2012. Applications of MALDI-TOF mass spectrometry in clinical diagnostic microbiology. FEMS Microbiol. Rev. 36:380-407. https://doi.org/10.1111/j $.1574-6976.2011 .00298 \times x$.

Dat, N. M., L. D. Manh, D. Hamanaka, D. V. Hung, F. Tanaka, and T. Uchino. 2014. Surface conditioning of stainless steel coupons with skim milk, buttermilk, and butter serum solutions and its effect on bacterial adherence. Food Control 42:94-100. https://doi .org/10.1016/j.foodcont.2014.01.040.

de Oliveira, G. B., L. Favarin, R. H. Luchese, and D. McIntosh. 2015. Psychrotrophic bacteria in milk: How much do we really know? Braz. J. Microbiol. 46:313-321. https://doi.org/10.1590/S1517 $-838246220130963$.

Duanis-Assaf, D., D. Steinberg, Y. Chai, and M. Shemesh. 2016. The LuxS based quorum sensing governs lactose induced biofilm formation by Bacillus subtilis. Front. Microbiol. 6:1517. https://doi.org/ 10.3389/fmicb.2015.01517.

Duncan, S. E., B. R. Yaun, and S. S. Sumner. 2004. Microbiological Methods for Dairy Products. 17th ed. J. Bruhn, ed. American Public Health Association, Washington DC.

Elhariry, H. M. 2011. Attachment strength and biofilm forming ability of Bacillus cereus on green-leafy vegetables: Cabbage and lettuce. Food Microbiol. 28:1266-1274. https://doi.org/10.1016/j.fm.2011 .05 .004 .

Faille, C., T. Bénézech, G. Midelet-Bourdin, Y. Lequette, M. Clarisse, G. Ronse, A. Ronse, and C. Slomianny. 2014. Sporulation of Bacillus spp. within biofilms: A potential source of contamination in food processing environments. Food Microbiol. 40:64-74. https:// doi.org/10.1016/j.fm.2013.12.004.

Hamadi, F., F. Asserne, S. Elabed, S. Bensouda, M. Mabrouki, and H. Latrache. 2014. Adhesion of Staphylococcus aureus on stainless steel treated with three types of milk. Food Control 38:104-108. https://doi.org/10.1016/j.foodcont.2013.10.006.

Huck, J. R., M. Sonnen, and K. J. Boor. 2008. Tracking heat-resistant, cold-thriving fluid milk spoilage bacteria from farm to packaged product. J. Dairy Sci. 91:1218-1228. https://doi.org/10.3168/jds .2007-0697.

Hussain, M. S., and D. H. Oh. 2017. Substratum attachment location and biofilm formation by Bacillus cereus strains isolated from different sources: Effect on total biomass production and sporulation in different growth conditions. Food Control 77:270-280. https:// doi.org/10.1016/j.foodcont.2017.02.014.

Ivy, R. A., M. L. Ranieri, N. H. Martin, H. C. den Bakker, B. M. Xavier, M. Wiedmann, and K. J. Boor. 2012. Identification and characterization of psychrotolerant sporeformers associated with fluid milk production and processing. Appl. Environ. Microbiol. 78:1853-1864. https://doi.org/10.1128/AEM.06536-11.

Jindal, S., S. Anand, L. Metzger, and J. Amamcharla. 2018. Short communication: A comparison of biofilm development on stainless steel and modified-surface plate heat exchangers during a 17-h milk pasteurization run. J. Dairy Sci. 101:2921-2926. https://doi .org/10.3168/jds.2017-14028.
Khoza, S. 2015. Effect of extended shelf-life milk processing on the bacterial composition associated with the nozzles of filling machines. MS Thesis, Department of Consumer and Food Sciences, University of Pretoria, Pretoria, South Africa.

Legeay, G., A. Coudreuse, F. Poncin-Epaillard, J. M. Herry, and M. N. Bellon-Fontaine. 2010. Surface engineering and cell adhesion. J. Adhes. Sci. Technol. 24:2301-2322. https://doi.org/10.1163/ $016942410 X 508037$.

Li, X., Z. Yan, and J. Xu. 2003. Quantitative variation of biofilms among strains in natural populations of Candida albicans. Microbiology 149:353-362. https://doi.org/10.1099/mic.0.25932-0.

Lindsay, D., V. S. Brözel, and A. Von Holy. 2006. Biofilm-spore response in Bacillus cereus and Bacillus subtilis during nutrient limitation. J. Food Prot. 69:1168-1172. https://doi.org/10.4315/0362 -028X-69.5.1168.

Lopez, D., H. Vlamakis, and R. Kolter. 2009. Generation of multiple cell types in Bacillus subtilis. FEMS Microbiol. Rev. 33:152-163. https://doi.org/10.1111/j.1574-6976.2008.00148.x.

Lorenzen, P. C., I. Clawin-Rädecker, K. Einhoff, P. Hammer, R. Hartmann, W. Hoffmann, D. Martin, J. Molkentin, H. G. Walte, and M. Devrese. 2011. A survey of the quality of extended shelf life (ESL) milk in relation to HTST and UHT milk. Int. J. Dairy Technol. 64:166-178. https://doi.org/10.1111/j.1471-0307.2010 $.00656 . x$.

Lücking, G., M. Stoeckel, Z. Atamer, J. Hinrichs, and M. EhlingSchulz. 2013. Characterization of aerobic spore-forming bacteria associated with industrial dairy processing environments and product spoilage. Int. J. Food Microbiol. 166:270-279. https://doi .org/10.1016/j.ijfoodmicro.2013.07.004.

Machado, S. G., F. Baglinière, S. Marchand, E. Van Coillie, M. C. D. Vanetti, J. De Block, and M. Heyndrickx. 2017. The biodiversity of the microbiota producing heat-resistant enzymes responsible for spoilage in processed bovine milk and dairy products. Front. Microbiol. 8:302. https://doi.org/10.3389/fmicb.2017.00302.

Marlow, V. L., F. R. Cianfanelli, M. Porter, L. S. Cairns, J. K. Dale, and N. R. Stanley-Wall. 2014. The prevalence and origin of exoprotease-producing cells in the Bacillus subtilis biofilm. Microbiology 160:56-66. https://doi.org/10.1099/mic.0.072389-0.

Martin, N. H., K. J. Boor, and M. Wiedmann. 2018. Symposium review: Effect of post-pasteurization contamination on fluid milk quality. J. Dairy Sci. 101:861-870. https://doi.org/10.3168/jds .2017-13339.

Meng, L., Y. Zhang, H. Liu, S. Zhao, J. Wang, and N. Zheng. 2017. Characterization of Pseudomonas spp. and associated proteolytic properties in raw milk stored at low temperatures. Front. Microbiol. 8:2158-7. https://doi.org/10.3389/fmicb.2017.02158.

Mugadza, D. T., and E. Buys. 2018. Bacillus and Paenibacillus species associated with extended shelf life milk during processing and storage. Int. J. Dairy Technol. 71:301-308. https://doi.org/10.1111/ 1471-0307.12474.

Mugadza, D. T., and E. M. Buys. 2017. Diversity of Bacillus cereus strains in extended shelf life. Int. Dairy J. 73:144-150. https://doi .org/10.1016/j.idairyj.2017.06.001.

Mugadza, D. T., R. Owusu-Darko, and E. M. Buys. 2019. Short communication: Source tracking Bacillus cereus in an extended-shelflife milk processing plant using partial sequencing of $\mathrm{rpoB}$ and multilocus sequence typing. J. Dairy Sci. 102:135-139. https://doi .org/10.3168/jds.2018-14733.

Peña, W. E. L., N. J. de Andrade, N. F. F. Soares, V. O. Alvarenga, S. Rodrigues Junior, D. Granato, A. D. G. Zuniga, and A. de Souza Sant'Ana. 2014. Modelling Bacillus cereus adhesion on stainless steel surface as affected by temperature, $\mathrm{pH}$ and time. Int. Dairy J. 34:153-158. https://doi.org/10.1016/j.idairyj.2013.08.006.

Quigley, L., O. O'Sullivan, C. Stanton, T. P. Beresford, R. P. Ross, G. F. Fitzgerald, and P. D. Cotter. 2013. The complex microbiota of raw milk. FEMS Microbiol. Rev. 37:664-698. https://doi.org/10 .1111/1574-6976.12030.

Rooney, A. P., N. P. J. Price, C. Ehrhardt, J. L. Swezey, and J. D. Bannan. 2009. Phylogeny and molecular taxonomy of the Bacillus subtilis species complex and description of Bacillus subtilis ssp. 
inaquosorum ssp. nov. Int. J. Syst. Evol. Microbiol. 59:2429-2436. https://doi.org/10.1099/ijs.0.009126-0.

Rosenberg, M., D. Gutnick, and E. Rosenberg. 1980. Adherence of bacteria to hydrocarbons: A simple method for measuring cellsurface hydrophobicity. FEMS Microbiol. Lett. 9:29-33. https:// doi.org/10.1111/j.1574-6968.1980.tb05599.x.

Seale, R. B., S. H. Flint, A. J. McQuillan, and P. J. Bremer. 2008. Recovery of spores from thermophilic dairy bacilli and effects of their surface characteristics on attachment to different surfaces. Appl. Environ. Microbiol. 74:731-737. https://doi.org/10.1128/ AEM.01725-07.

Sharma, M., and S. K. Anand. 2002. Biofilms evaluation as an essential component of HACCP for food/dairy processing industry - A case. Food Control 13:469-477. https://doi.org/10.1016/S0956 $-7135(01) 00068-8$.

Soni, A., I. Oey, P. Silcock, and P. Bremer. 2016. Bacillus spores in the food industry: A review on resistance and response to novel inactivation technologies. Compr. Rev. Food Sci. Food Saf. 15:11391148. https://doi.org/10.1111/1541-4337.12231.

Srey, S. I. K. Jahid, and S.-D. Ha. 2013. Biofilm formation in food industries: A food safety concern. Food Control 31:572-585. https: //doi.org/10.1016/j.foodcont.2012.12.001.

Stepanović, S., D. Vuković, I. Dakić, B. Savić, and M. Švabić-Vlahović. 2000. A modified microtiter-plate test for quantification of staphylococcal biofilm formation. J. Microbiol. Methods 40:175-179. https://doi.org/10.1016/S0167-7012(00)00122-6.

Teh, K. H., S. Flint, J. Palmer, P. Andrewes, P. Bremer, and D. Lindsay. 2012. Proteolysis produced within biofilms of bacterial isolates from raw milk tankers. Int. J. Food Microbiol. 157:28-34. https:// doi.org/10.1016/j.ijfoodmicro.2012.04.008.

Teh, K. H., S. Flint, J. Palmer, P. Andrewes, P. Bremer, and D. Lindsay. 2014. Biofilm-An unrecognised source of spoilage enzymes in dairy products? Int. Dairy J. 34:32-40. https://doi.org/10.1016/j .idairyj.2013.07.002.
Tirumalai, P. S. 2015. Metabolic gene expression shift by Listeria monocytogenes in coculture biofilms. Can. J. Microbiol. 61:327334. https://doi.org/10.1139/cjm-2014-0704.

Veening, J.-W., W. K. Smits, and O. P. Kuipers. 2008. Bistability, epigenetics, and bet-hedging in bacteria. Annu. Rev. Microbiol. 62:193-210. https://doi.org/10.1146/annurev.micro.62.081307 .163002 .

Vithanage, N. R., M. Dissanayake, G. Bolge, E. A. Palombo, T. R. Yeager, and N. Datta. 2016. Biodiversity of culturable psychrotrophic microbiota in raw milk attributable to refrigeration conditions, seasonality and their spoilage potential. Int. Dairy J. 57:8090. https://doi.org/10.1016/j.idairyj.2016.02.042.

von Neubeck, M., C. Baur, M. Krewinkel, M. Stoeckel, B. Kranz, T. Stressler, L. Fischer, J. Hinrichs, S. Scherer, and M. Wenning. 2015. Biodiversity of refrigerated raw milk microbiota and their enzymatic spoilage potential. Int. J. Food Microbiol. 211:57-65. https://doi.org/10.1016/j.ijfoodmicro.2015.07.001.

Whitehead, K. A., and J. Verran. 2015. Formation, architecture and functionality of microbial biofilms in the food industry. Curr. Opin. Food Sci. 2:84-91. https://doi.org/10.1016/j.cofs.2015.02.003.

Wirtanen, G., U. Husmark, and T. Mattila-Sandholm. 1996. Microbial evaluation of the biotransfer potential from surfaces with Bacillus biofilms after rinsing and cleaning procedures in closed foodprocessing systems. J. Food Prot. 59:727-733. https://doi.org/10 .4315/0362-028X-59.7.727.

\section{ORCIDS}

J. A. Elegbeleye @ https://orcid.org/0000-0002-0162-7708

E. M. Buys (ํ) https://orcid.org/0000-0001-7836-9295 